\title{
THE INFLUENCE OF PRIVACY AND TRUST ON THE ADOPTION OF INTERNET BANKING IN BANGLADESH
}

\author{
MOHAMMAD A. ASHRAF \\ MIRZA M. D. ALAM \\ MUHAMMAD S. I. NOOR \\ School of Business \\ United International University, Bangladesh
}

\section{Abstract}

In Bangladesh, the expansion of Internet banking is beset with several infrastructural, institutional, and regulatory constraints. Despite the constraints, efforts by the Bangladesh Bank in modernizing the country's payment system and commitment by the government in building 'Digital Bangladesh' have brought competition among the scheduled banks to improve banking services and rapidly adopt Internet banking on a wider scale. However, several opinion polls have revealed that many clients are found reluctant in adopting banking via the Internet because of their concerns about the privacy of the personal information they provide to online. Using the theory of planned behaviour as its theoretical basis, this study examined the relationships among beliefs about Internet privacy and trust, along with beliefs about perceived behavioural control and the expectations of important others and online banking behaviour. Data were collected from 327 university students. Analysis of the data indicates that beliefs about trust and privacy positively affect attitudes toward Internet banking, but attitude is found not to significantly affect Internet banking behaviour. Normative beliefs positively affect subjective norms which in turn affect Internet banking behaviour. Similarly, beliefs about self-efficacy regarding Internet banking positively affect perceived behavioural control, which in turn affects actual online banking behaviour.

Keywords: Internet banking, privacy, trust, subjective norms, perceived behavioural control.

\section{Introduction}

Advances in information and communication technologies, particularly in growing Internet use for business transaction, have had a profound impact on the banking industry (Durkin, 2007). Compared to developed countries, uses of Internet banking lag much behind in developing societies. Economic backwardness, massive illiteracy and poor infrastructure are, amongst others, slowing down the rate of adoption of technology in these less-developed countries and Bangladesh is one of them. Bangladesh Bank (the Central Bank of Bangladesh) recently introduced online payment systems facilitating fund transfers and payment of utility bills on the Internet. This move will certainly enhance the use of e-commerce and Internet banking services facilitating financial transactions of the subscribers of all commercial banks in Bangladesh. Despite all these potentials, these systems remain unnoticed as well as underused by the customers (Byron \& Ahmed, 2009). Several experts such as Cranor (2007), Gambi (2009) and Dwyer, Hiltz and Passerini (2007) argue that in the case of adoption of Internet banking, privacy and trust are the most important issues that play a significant role. 
Prior to the Internet revolution, traditional brick-and-mortar banking was the fundamental stronghold for years in the banking industry. Today, the emergence of Internet banking offers self-service channels and entire hassles are about to be over. Shoppers now need not go to market spending hours in traffic jams. Similarly one does not need to stand in long queues to pay utility bills. All are now possible to be done on the internet (Chang \& Hamid, 2010).

Yet, people are observed to be reluctant to adopt Internet banking in Bangladesh (Byron \& Ahmed, 2009), which may jeopardize the recent public endeavour of adopting digital banking in Bangladesh. Thus, there is a need to explore the factors of users' acceptance of Internet banking that can affect their intention to use it. Unfortunately, there is no such comprehensive study available that attempts to determine those forces which supposedly slow down the user's adoption of Internet banking in Bangladesh. This consideration is momentous to the practitioners who plan and promote this new form of banking in the concurrent competitive market environment of Bangladesh (Shih \& Fang, 2004).

The main purpose of this paper is, therefore, to investigate the relationship between Internet banking and beliefs about the privacy and trustworthiness of the Internet among the consumers in Bangladesh. Particularly, how individual beliefs about privacy and trustworthiness of the Internet influence individual intentions to adopt Internet banking behaviour is to be explored. With this end in view, a research framework was constructed for this study based on the Theory of Planned Behaviour (TPB) developed by Ajzen (1991). By means of the measurement scales fashioned to examine different facets of privacy and trustworthiness, perceived behavioural control and subjective norms, a set of questionnaire was generated in order to test the various links originally introduced by TPB.

The plan for this paper is as follows: first, the TPB is briefly reviewed, as are the relevant literature on Internet privacy and trustworthiness. Next, the research model and hypotheses are presented, followed by a discussion of the research method and the findings from the data analysis. A discussion of the meaning of the results and their implications concludes the paper.

\section{Internet Banking Issues in Bangladesh}

A strong banking industry can have a significant impact on attaining faster pace in economic development through efficient and innovative financial services (Salehi \& Zhila, 2008). One of such financial services is Internet banking. However, numerous challenges and issues are involved in it. As Internet banking is in its nascent stage in Bangladesh, it faces numerous bottlenecks. One such major obstacle is the issue of trust and reliability of Internet banking transaction (Mia et al., 2007). Another issue is related to the privacy concern which thwarts the customers in Internet banking activities (Salehi et al., 2008).

Recent data show that by the year 2007 in Bangladesh, 29 out of 48 banks had offered online financial services which included Internet Banking (Rahman, 2007). A few per cent of Internet users in Bangladesh have used Internet Banking (Bakta \& Sarder, 2007). As the Internet service is now widely used in Bangladesh, the proportion of banking over the Internet is expected to grow at a high speed. A more recent study found that the growth of Internet banking in Bangladesh is not substantial (Baten \& Kamil, 2010). This finding squares with the results of past studies of the reasons why Internet users have been hesitant to bank online. For example, (Azam, 2007) in a report on electronic commerce issue, reported that privacy is the overriding concern. A study of Awal (2004) demonstrates that the trust and reliability issue is found as a robust concern among the Internet users in Bangladesh.

\section{Theory and Past Research}

This study employs the Theory of Planned Behaviour (TPB) (Ajzen, 1985, 1991) as its theoretical framework which is actually an 
extension of the Theory of Reasoned Action (TRA) (Ajzen \& Fishbein, 1980). The added feature of the extension is characterized by an ability to deal with behaviours over which individuals possess complete volitional control. TRA introduced two endogenous variables of attitude toward behaviour and subjective norms in its design to influence intention which subsequently realizes into the actual behaviour. TPB annexed this design with an additional engagement of another independent variable named perceived behavioural control that affects intention toward engaging in the behaviour (see Figure 1).

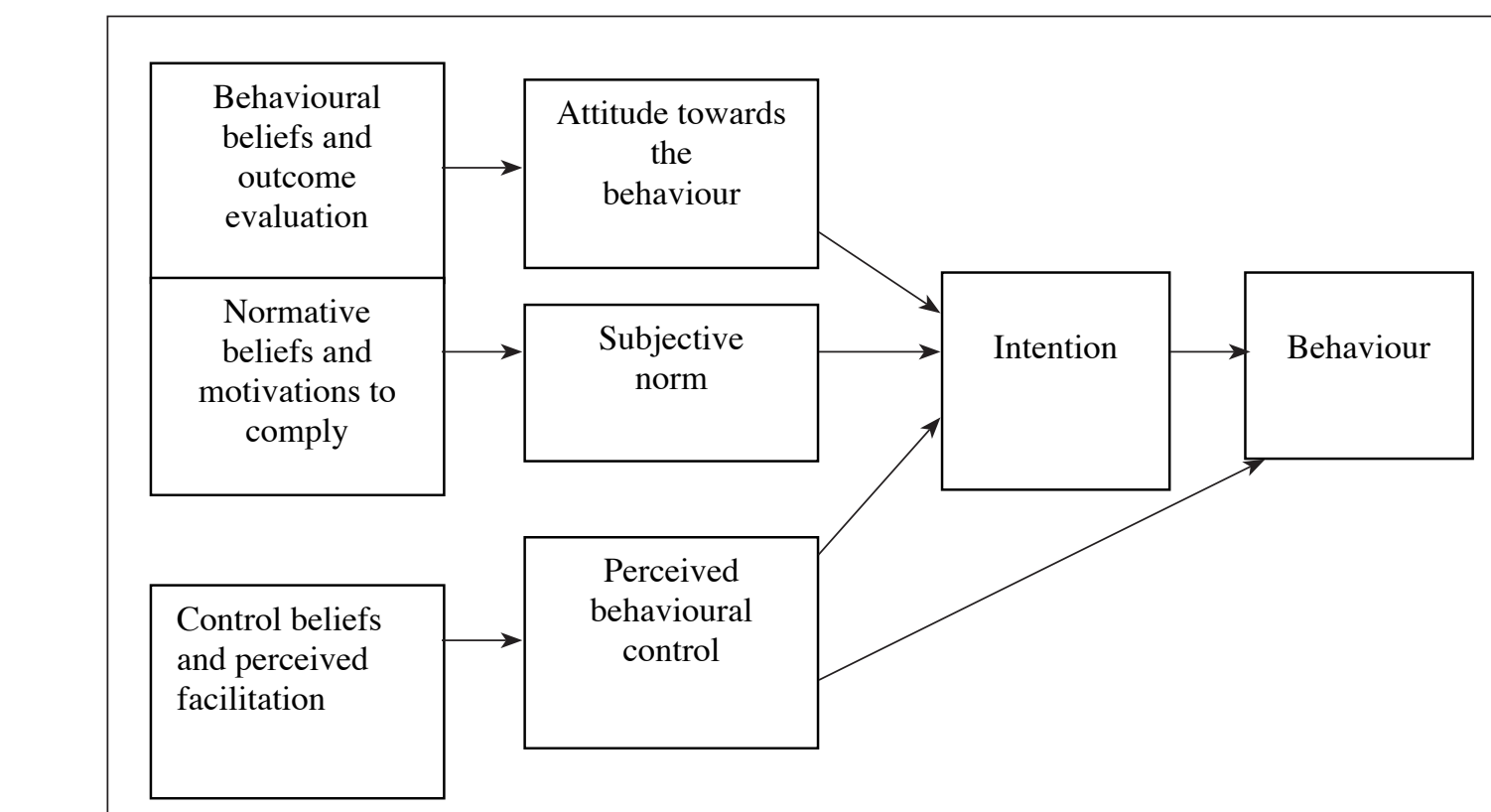

Source. Ajzen, I. (1991). The theory of planned behaviour. Organizational Behaviour and Human Decision Processes, 50, p. 179-211.

Figure 1. The theory of planned behaviour.

In fact, TPB achieved immense popularity in terms of analysing the intentional behaviour of an individual in adopting any kind of innovative and new objects introduced by the scientists. Over the last two decades after its inception, myriads of studies have been accomplished entwining TPB as their core framework of analysis in the field of applied psychology as well as in information science and technology (Suh \& Han, 2003; Song \& Zahedi, 2001; Tan \& Teo, 2000). Specifically, how do individual beliefs about privacy and trust of the Internet influence individual intentions to do Internet banking and have actual Internet banking behaviour? To answer this question, the theory of planned behaviour (TPB) is the most suitable tool (George, 2002; Khalifa \& Limayem, 2003; Limayem, Khalifa \& Frini, 2000; Pavlou, 2002) Using measurement scales created to assess different aspects of privacy and trust, as well as perceived behavioural control and subjective norms, a survey instrument was developed for this study to test the various relationships implied by TPB. 
According to Ajzen (1985), an attitude toward a behaviour is a positive or negative evaluation of executing that behaviour. Attitudes are cognized by beliefs; norms are cognized by normative beliefs and motivation to comply and perceived behavioural control is cognized by beliefs about the individual's possession of the opportunities and resources needed to be involved in the behaviour (Ajzen, 1991). TPB's perceived behavioural control is comparable to Bandura (1997) which introduces the concept of perceived self-efficacy. Besides, there has been a direct connection between perceived behavioural control and actual behaviour. Given two individuals with the same level of intention to be engaged in a behaviour, the one with more confidence in his or her abilities is more likely to succeed than the one who is confused (Ajzen, 1991). Theoretically, TPB does not specify a particular set of beliefs associated with any particular behavior which leaves room for the researchers to choose those beliefs on their own.

\section{Privacy}

Privacy is one of the major concerns of Internet users (Cranor, 2000). The integration of banking into the Internet aggravates this concern (Langendorfer, 2002). In TORT law, privacy is a right not to have one's intimate life and affairs exposed to public view or otherwise invaded (Britannica, 2006). As technology has advanced, the way in which privacy is protected and violated has changed with it. In the case of some technologies, such as the Internet, the increased ability to share information can lead to new ways in which privacy can be breached. The first publication, according to Swire and Bermann (2007), is Warren and Brandeis (1890) which advocate privacy of personal information urging that the individual should have full protection in person and in property. And this is the most important concern for which bank-clients do not want to make online banking over the Internet.

The social networking landscape has attracted considerable media attention (Cole \& Brooks,
2009). Reports of exponential adoption and use of social networking sites have been replaced by stories concerning the problems and dangers of digitally-networked individuals operating in a global village (Albrechtslund, 2008). It has two different theoretical aspects of privacy; a social networking relationship (Shin, 2010; Fogel \& Nehmad, 2009) and a property relationship (Litman, 2000; Samuelson, 2000). In the view of social relationships, privacy is understood to act as a balance to the development of social relationships. Privacy is not defined as the right to be let alone as it is an important mechanism in the social processes. This notion of privacy on the Internet would be marked in anonymous connections and hidden identities, as in chat rooms, where social networking relationships among clients of different Internet communities are identified (Parameswaran \& Whinston, 2007). In the property link, individuals perceive privacy as the degree to which they administer their own information in all kinds of cyberspace exchanges. The property aspect incorporates itself in volitional exchanges of private information in exchange for important services such as free e-mail or special discounts from business magnets. Hence, privacy appears to be a decisive problem for using Internet banking. This consideration usually does not arise with purely human participants, since it is generally thought that they can keep their private values secret. Even if current information can be safeguarded, records of past behaviour can be extremely valuable, since historical data can be used to estimate the willingness to pay. What should be the technological and social safeguards to deal with this problem (Varian, 1992)?

While the notions of privacy are central to apprehending individual behaviour on the Internet, the majority of the apprehensions about privacy linked to Internet banking appear to undergo the property relation of privacy. For instance, outcomes from the 1997 GVU Internet surveys point out that 53 per cent of online clients are afraid of the gathering of private information by commercial Websites, and 66 per cent do not chronicle with the Web-site for trepidation that their private information may be mishandled 
(GVU, 1997). A recent study of Miyazaki and Fernandez (2001) suggests that respondents were observed to express their own apprehensions about Internet banking. Among the respondents 5.6 per cent identified the unlawful sharing of private information as one of their central concerns about Internet transaction, while 7.1 per cent identified unlawful intrusion to personal information, and 20.1 per cent identified unlawful entrée to credit card information.

Privacy has been discussed in various forms and settings for more than 100 years by lawyers, philosophers, sociologists, psychologists, economists, technicians, politicians and other stakeholders. One of such studies is Weiss (2009). This paper reports the major requirements for developing privacy-preserving social network applications and proposes a privacy-threat model that can be used to enhance the information privacy in data or social network portability initiatives by determining the issues at stake related to the processing of personally identifiable information.

Wright et al. (2009) contend that the emerging ubiquitous Information society will raise many privacy issues that are context dependent. These issues will pose many challenges for policy-makers and stakeholders, because people's concept of privacy is different and shifting. People's attitudes towards privacy and protecting their personal information can diverge significantly according to differing circumstances. Besides, the concept of privacy is changing over time. The authors offer numerous instances of the challenges facing policy-makers and identify some potential responses, but they perceive a necessity for upgrading in the policymaking process in order to deal more effectively with varying contexts. They also identify some useful policy-making tools. The study concludes that the broad policies of the past are not likely to be enough to deal with the new challenges and that we are possibly entering an era that will need development of "micro-policies". While the new technologies will pose many challenges, perhaps the biggest challenge of all will be to ensure coherence of these micro-policies.
Despite the recent economic downturn in the Internet and telecommunication sectors, electronic commerce continues to grow and corporate web-sites remain an important communication channel. Nonetheless, justifiable concerns regarding privacy and confidentiality remain potential bottlenecks to growth and vital issues to both individuals and organizations. In this regard, Liu et al. (2005) proposed and tested a theoretical model that considers an individual's perceptions of privacy and how it relates to one's behavioural intention to make an online transaction. An experiment that included over 200 subjects was conducted using two web-sites that differed only by the privacy dimensions of their notice, access, choice, and security. The results of this study suggested strong support for the model.

It is virtually a truism that self-disclosure is crucial for personal and relationship well-being. Frye and Dornisch (2010) investigated whether topics of intimacy and perceived privacy predict levels of comfort with disclosure and whether these relationship are moderated by overall levels of trust and frequency of technology utilization. Participants reported on the degree to which they would feel comfortable discussing each of topics using dissimilar various communication tools. Topics and tools interacted here such that the privacy of the communication tools was linked to be disclosure of comfort only for intimate topics. Privacy concerns were more significant to less frequent technology users and topic intimacy concerned most to participants with low levels of trust.

Depending on the previous studies on information technology and privacy with its special interest to unlawful use of personal data and given the predominance of consumer apprehensions about the exploitation and illegal sharing of their private information, beliefs about privacy are stylized in this investigation in terms of the lawful utilization and sharing of personal information by Internet authorities that gather it. This method essentially deviates from past researches that have measured the role of privacy in Internet banking. 


\section{Trust}

Trust is defined as the willingness of a party to be vulnerable to the actions of another party based on the expectation that the other will perform a particular action important to the person who trusts, irrespective of the ability to monitor or control that other party (Dwyer et al., 2007). The increasing importance of trust is reflected in many studies that propose trust as a central concept such as Gambi (2009), Joinson (2008), Maheswaran, Tang and Ghunaim (2007), Coppola, Hiltz, and Rotter (2004), Metzger (2004), Piccoli and Ives (2003), Boyd (2003), McKnight, Choudhury and Kacma (2002), Jarvenpaa et al. (2000), and Lee and Turban (2001).

Highlighting the increasing importance of trust, Dwyer et al. (2007) proposes trust as a central concept: as a subsequent variable of perceived security and privacy and as an antecedent variable to attitudes toward networking behaviour. McKnight, Choudhury and Kacma (2002) report that in human interactions trust has always been a significant factor in exchanges involving risk. As trust has been a critical factor in networking it has been extensively addressed as a research topic from different viewpoints and to different levels of analysis.

In daily face-to-face interactions, trust is a critical antecedent for exchanging information and developing new relationships (Coppola, Hiltz \& Rotter, 2004; Jarvenpaa \& Leidner, 1998; Piccoli \& Ives, 2003). Trust is also important for successful online interactions. Metzger (2004) shows that e-commerce research has found trust as strongly related to information disclosure. Studies of interpersonal-exchange situations confirm that trust is a precondition for self-disclosure because it reduces perceived risks involved in revealing private information. Papadopoulou (2007) finds a positive influence of trust on attitude and intentions. The higher the client's trust in the web, the less effort clients will put forth to examine details of the site to judge its authenticity of services. On a site which is trustworthy, they will not squander time and effort and thus will experience higher ease of use. The effect of trust on attitudes is hinged on the integrity dimension of the trust. Recently, trust has taken center stage as a serious issue in networking (Gambi, 2009; Maheswaran, Tang \& Ghunaim, 2007). It is thus timely and rational to investigate that trust of online transactions influences the release of private data to the web-site. If trust is specifically important to the course of social interaction, then it is vital to ask what fosters the trust of a web-site. Anticipated determinants subsume trust, perceptions of website privacy protection, perception of security, client's overall online-privacy concerns and intention to use (Boyd, 2003; Jarvenpaa et al., 2000; Joinson, 2008; Metzger, 2004).

The significance of trust as a key catalyst of electronic transaction is increasingly being accredited in academic and business communities (Bhattacherjee, 2002; Huang et al., 2003). Customer trust is essential to the success of transactions through online for two reasons. First, online transactions often require the sharing of sensitive personal, corporate, and financial data among the transacting parties (Lee \& Turban, 2001). Second, in the online transactions, clients routinely transact with whom they have had little or no prior interaction (Pavlou \& Gefen, 2004).

An individual's attitude toward Internet banking can be thought of in terms of trust (Kim \& Ahn, 2007). Numerous customers do not trust web providers with their private information to engage in exchanges with them (Hoffman, Novak \& Peralta, 1999). Although trust has been defined in various ways, a particularly precise definition is "that one believes in, and is willing to depend on, another party" (McKnight, Cummings \& Chervany, 1998, p. 474). Trust persists only when those involved "are assured of others' volition and ability to cater to their obligations" (Ratnasingham, 1998,p. 314). In view of customer relations in the field of online transactions over the trustworthiness of the Internet, it should not be surprising that a recent laboratory experiment found subjects of perceived Internet use as more risky than traditional methods (Jones \& Vijayasarathy, 1998). Customer perspectives of the trustworthiness of the Internet, thus, should 
be anticipated to affect their willingness to transact online.

\section{Research Model and Hypotheses}

The research framework used in the study, presented in Figure 2, is hinged on TPB. The actual behaviour in question is banking over the Internet. As cited previously, the typical TPB model would resort to the intention to make Internet banking as a determinant to banking behaviour. While the data in this study were all collected at one point in time, it is not possible to include both the intention to perform a behaviour and the behaviour itself in the model. Intentions imply future behavior, while reports of actual behaviour imply what happened in the past. Past behaviour is at best a proxy for future behaviour and not always a good one (George, 2000). Intention, therefore, does not appear in the framework and instead there has been a direct path from attitudes towards Internet banking behaviour. The relation between subjective norms and banking is also introduced as a direct relationship here. In the same way, a typical TPB model has been constructed based on the relationship between perceived behavioural control and behavior to be both direct and mediated by intention, but the mediating relationship has been omitted in this model owing to the absence of the variable, intention (George, 2000). So, the direct relationship between PCB and actual behaviour remains intact. Two sets of beliefs are articulated that measures attitudes toward Internet banking and they are:

Beliefs about Internet trustworthiness [based on the work by Hoffman et al. (1999), and Jones and Vijayasarathy (1998)], in order to see whether the Internet could be trusted for conducting personal business with banking; and

(2) Beliefs about the unlawful secondary use of private information (Culnan, 1993; Smith, Milberg \& Burke, 1996), particularly whether business organizations should be able to use private data without permission.

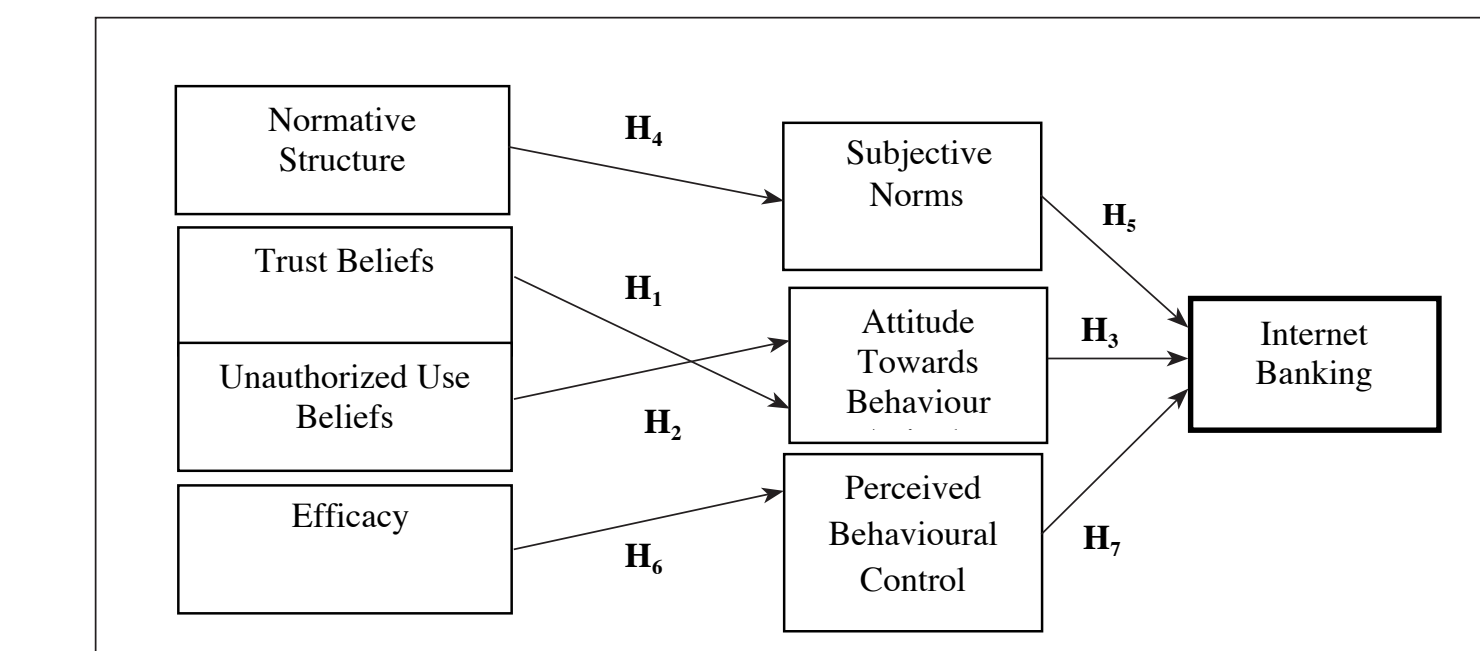

Figure 2. Research model along with the specification of hypotheses.

Seven hypotheses are developed in this study. The direction specified in each hypothesis is constructed from the previous discussion of different beliefs about privacy and from the original design of TPB. Beliefs in the trustworthiness of the Internet ought to be 
linked with the willingness to carry out banking online. If a person believes that the Internet is a trustworthy avenue for carrying out private banking, then those beliefs should positively impact the personal attitudes toward using the Internet for banking activities.

Hypotheses 1 and 2 are proposed based on the research model which incorporates trust and privacy as two important antecedents of Internet banking. The remaining five hypotheses $3,4,5,6$ and 7 have been advanced based on TPB. Positive attitudes toward the behaviour in question ought to result in the manner of that behaviour. Thus, the hypotheses are:

Hypothesis 1: Beliefs that the Internet is trustworthy should positively (1)

Hypothesis 2: Beliefs that a company $\frac{E}{5}$

Hypothesis 3:

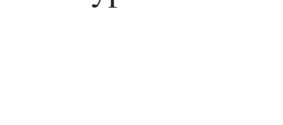

Hypothesis 4:

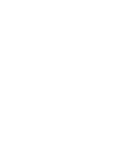

Hypothesis 5: Subjective norms about Internet banking should positively influence online banking behaviour.

Hypothesis 6: Positive beliefs about selfefficacy of doing Internet banking should positively influence perceived behavioural control over doing Internet banking.

Hypothesis 7: Positive beliefs about perceived behavioural control should positively influence online banking behaviour.
The data collection exercises were aimed at gathering information on the impact of privacy and trustworthiness on the attitude toward adoption of Internet banking in Bangladesh. To this aim, data were collected using self-complete closedend-questionnaires from 500 students of one of the top-ranked private universities in Bangladesh during the period of January to February 2010. The questionnaire was constructed on a 7-point scale. In the measurement, scale 1 indicates strongly disagree and scale 7 indicates strongly agree. The questionnaire was pilot-tested with a small number of students of the university. Descriptive statistics of the sample are provided in Table 1.

Table 1

\section{Sample Statistics}

\begin{tabular}{ccc}
\hline \multirow{2}{*}{ Age } & Mean (Years) & 25.99 \\
& SD (Years) & 9.39 \\
Gender & Male & $74.6 \%$ \\
& Female & $25.4 \%$ \\
& $<1$ year & $15.3 \%$ \\
Internet & 1 to 3 years & $38.8 \%$ \\
Experience & 4 to 6 years & $25.4 \%$ \\
& $\geq 7$ years & $20.5 \%$ \\
Owned PC & Yes & $96.6 \%$ \\
& No & $3.4 \%$ \\
\hline
\end{tabular}

The approach adopted in this study was originally used by Taylor and Todd (1995) to test a TPB model with decomposed belief structures. Following this method, measures of attitude (four items), subjective norms (two), perceived behavioural control (three), normative structure (four) and self-efficacy (four) were developed. For measuring the trustworthiness of Internet banking, items (four) were included according to Jarvenpaa et al. (1998) who adapted the 
method developed by Pearce et al. (1994). Items measuring the beliefs about the unauthorized secondary use of personal information were based on Culnan's scale (1993).

Actual Internet banking behaviour was measured with a single item, "How many times would you say you would do banking over the internet per month?" Although multiple-item scales were preferred in most cases, a single item would be enough in some instances, as when individuals could be counted on to respond to a single item with relatively high degrees of accuracy (DeVellis, 2003). However, a few demographic questions were included in the questionnaire which is provided in the appendix. The descriptive statistics for the scale are represented in Table 2.

\section{Table 2}

Descriptive Statistics for Constructs

\begin{tabular}{lccccc}
\hline \multicolumn{1}{c}{ Construct } & $\mathrm{n}$ & Minimum & Maximum & Mean & SD \\
\hline Attitude & 327 & 1.50 & 7.00 & 6.2294 & .83913 \\
Unauthorized Secondary Use & 327 & 1.00 & 7.00 & 4.1919 & .84273 \\
Internet Trustworthiness & 327 & 1.25 & 7.00 & 5.3425 & 1.02581 \\
Subjective Norms & 327 & 1.00 & 7.00 & 5.1911 & 1.21633 \\
Normative Structure & 327 & 1.33 & 7.00 & 4.7727 & 1.18657 \\
Perceived Behavioural Control & 327 & 1.00 & 7.00 & 5.7085 & 1.17950 \\
Control Structure: (Self -Efficacy) & 327 & 1.40 & 7.00 & 5.6820 & 1.02083 \\
Internet Banking & 327 & 1.00 & 7.00 & 3.7231 & 1.72944 \\
\hline
\end{tabular}

The data were analyzed using SPSS/AMOS 16. The study ran the model in Figure 2 first. In order to check internal consistency, Cronbach alphas were calculated for the constructs. These alpha values along with the correlation coefficients are shown in Table 3. The statistical significance of the paths in the model was tested. In the tests, six of the seven paths were statistically significant, one at the $p<.10$ level, one at the $p<.05$ level and four at the $p<.01$ level, providing support for $\mathrm{H} 2, \mathrm{H} 5$ and $H 1, H 4, H 6, H 7$ respectively. The evaluated model is shown in Figure 3.

\section{Results and Discussion}

This study was done in order to check Internet banking behaviour in the context of Bangladesh. One of the most important findings of the study demonstrates that attitude towards Internet banking is statistically insignificant (H3) implying that the general attitude of the people has not yet been shaped to adopt internet banking practice at this particular stage of time. The main reason behind this outcome may be associated with very recently introduced Internet banking practice in the nascent financial horizon of Bangladesh where people are not yet mentally ready to adopt this new practice.

As would be expected from the TPB, both the beliefs about trustworthiness $(H I)$ and unauthorized use (H2) were found to significantly impact the attitude component. However, trustworthiness beliefs than unauthorized beliefs were found more important to the young student respondents. Beliefs about self-efficacy of using the internet for banking directly affected perceived behavioural control (H6) and PCB 
in turn directly influenced Internet banking behaviour (H7). In fact, Internet technology has become popular in Bangladesh since the early 1990s. Young students are already accustomed to using the Internet in other purposes of academic and nonacademic uses. In Table 1, it is obvious that more than 96 per cent of the respondents own personal computers. Thus, respondents who believed in their abilities to successfully engage in Internet banking behaviour engaged in Internet Banking practices. As expected, similar findings were also found in the cases of normative structure $(\mathrm{H} 4)$ and subjective norms (H5) to affect Internet banking behaviour.

Table 3

Correlation Coefficients and Reliability Measures

\begin{tabular}{lcccccccc}
\hline Constructs & Reliability & $\begin{array}{c}\text { Internet } \\
\text { Banking }\end{array}$ & Attitude & Unauthorized & Trust & $\begin{array}{c}\text { Subjective } \\
\text { Norm }\end{array}$ & $\begin{array}{c}\text { Normative } \\
\text { Structure }\end{array}$ & PBC \\
\hline $\begin{array}{l}\text { Internet } \\
\text { Banking }\end{array}$ & 1.00 & & & & & & \\
Attitude & 0.82 & 0.212 & & & & & \\
Unauthorized & $(0.14)$ & 0.034 & $(0.009)$ & & & & \\
Trust & 0.89 & 0.264 & 0.458 & 0.167 & & & \\
Subjective & 0.85 & 0.260 & 0.395 & $(0.012)$ & 0.458 & & \\
Norm & & & & & & & \\
\hline Normative & 0.84 & 0.281 & 0.319 & 0.045 & 0.406 & 0.603 & \\
Structure & 0.83 & 0.379 & 0.420 & 0.003 & 0.335 & 0.257 & 0.280 \\
\hline PBC & 0.82 & 0.418 & 0.618 & $(0.013)$ & 0.466 & 0.420 & 0.361 & 0.641 \\
\hline Efficacy & & & & & & & \\
\hline
\end{tabular}

Similar findings are reported in many other studies. For instance according to, like George - (2002), Pavlou (2002), and Suh and Han (2003), there was a strong relationship between trust and attitudes toward internet banking. Battacherjee (2000) and Song and Zahedi (2001) showed a similar strong relationship between normative structure and subjective norms. Limayem et al. (2000) and Khalifa and Limayem (2003) also found a similar strong relationship between PBC and actual Internet purchasing. Like Battacherjee (2000) but unlike Song and Zahedi (2001), there was a strong relationship between self-efficacy and PBC. However, the lack of a relationship between attitude and Internet banking contradicts the findings of such a relationship in Jarvenpaa and Todd (1997a, b) and George (2002).
In the present study, TPB served as a useful foundation to help explain Internet banking, even though the model used here deviated from TPB traditions by not including the intentional component. The direct relationship in TPB between perceived behavioural control and behaviour was found active here and the relationship between self-efficacy and PBC was strong. Typically in TPB models, the effects of subjective norms on behaviour would also be mediated by intention instead of the direct relationship posited here. That hypothesized direct relationship was fully supported showing the expected positive relationship between normative structure and subjective norms. In this case, it may be that parents, friends, professors and classmates were important to the students 


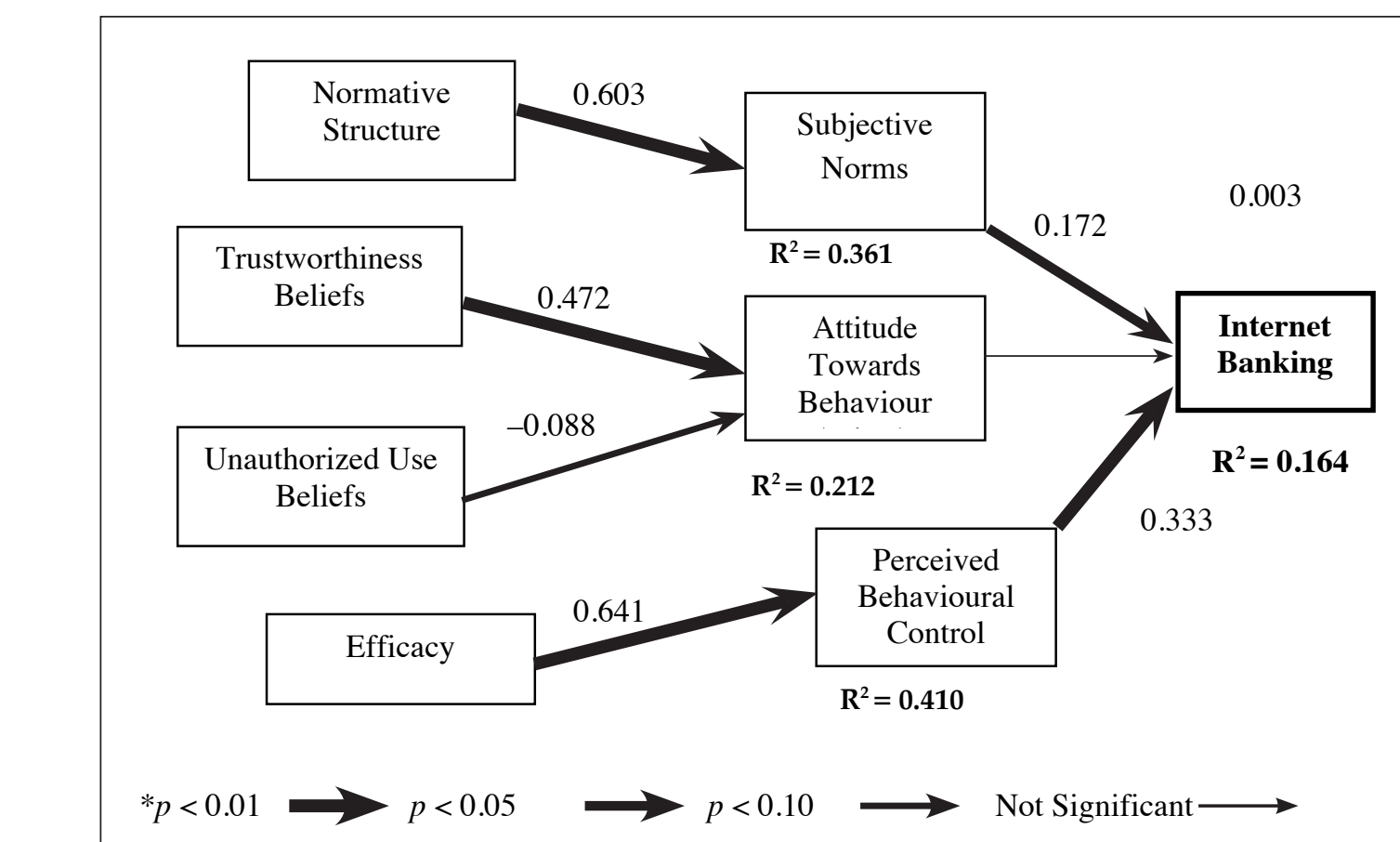

Figure 3. Evaluated model.*

who listened to them to determine their Internet banking behaviour.

In this study of Internet banking behaviour, the findings imply that consumers are swayed more by their perceptions about the trustworthiness of the Internet than by concerns they might have about unauthorized use of their personal information by other Internet users. Beliefs about improper access to personal information were less significant determinants of attitudes toward Internet banking than trustworthiness. As the secondary use of personal information has always been a robust topic in IS-related privacy literature (Byford, 1998; Culnan, 1993; Smith et al., 1996), so the finding of the present study is in perfect congruence with them. This finding could be due to the youth of the respondent group; with an average age just over 25 . This age group may not maintain the same perspectives about secondary use of information as the older generations.

\section{Conclusions, Implications for Future Research and Limitations of The Study}

This paper investigates the relations between Internet banking and beliefs about the privacy and trustworthiness of the Internet among the consumers in Bangladesh. From a research perspective, the study results demonstrate the robustness of the TPB in helping to explain Internet banking behaviour. The findings of the study reveal that both antecedents are important for forming the attitude from the respondents' perspectives, but trustworthiness is found comparatively more important than privacy or unauthorized uses of Internet banking. The study also exhibits that attitude towards Internet use for adopting online banking is at a budding stage in Bangladesh, since this antecedent is found statistically insignificant to affect actual Internet banking behaviour. With a considerable time lag in future, this scenario may change with 
the changing attitude towards Internet banking behaviour.

This study considers only two antecedents to examine attitudes toward the adoption of Internet banking behaviour. There may well be others that ought to be included in future research, such as other aspects of privacy which are used by Byford's (1998); social relationship and property views of privacy. However, suitable and reliable seales for these constructs need to be developed in order to incorporate them in future studies (George, 2002).

Future research could take account of measures of both the intention to adopt and the actual Internet banking behaviour. Since intention measures future behaviour and actual purchasing measures past behaviour, there should be a time lag between when intention is measured and when behaviour is measured. How long such a time lag should be is not always comprehensible. For instance, Davis et al. (1989) who tested the Technology Acceptance Model by incorporating TRA and waited 14 weeks between measuring intention and measuring behaviour. Fourteen weeks may be a long period to linger between measures of intention and actual Internet banking, but some time lag is essential. Nevertheless, measures of both intention and actual behaviour reinforce the outcomes of all TPB-based studies, even though past studies have typically showed a strong association between these two constructs (Azjen, 1991).

-

As with any study, there are limitations to this study as well. One possible shortcoming is the use of university students as respondents, even though they have extensive experience with the online world. In the sample used here, more than 45 per cent had 4 or more years of experience with the Internet. University students should have enough knowledge about the Internet and to answer questions about carrying out internet banking, and their beliefs about privacy and trustworthiness of the Internet. If anything, students may not be completely representative of the population at large only because they have more Internet experience. They may in fact represent the vanguard of Internet banking behaviour, providing insight into the potential behaviour of consumers to come.

Nevertheless, the customary cautions about over-generalizing results from this sample may apply to the population for which it is not strictly representative. The sample was not randomly taken to represent a population to which outcomes could be generalized, because it was a convenience sample for which the ability to generalize the findings very far beyond the sample was limited. However, the study would at least focus on the present status of the adoption of Internet banking in Bangladesh which might be useful to the public and private agents in order to boost this kind of practice in society in the near future.

\section{References}

Akinci, S., Safak, A., \& Eda, A. (2004). Adoption of internet banking among sophisticated consumer segments in an advanced developing country. International Journal of Bank Marketing, 22(3), 212-232.

Albrechtslund, A. (2008). Online social networking as participatory surveillance. First Monday, 13(3), 11-11.

Awal, M. A. (2004). Internet in Bangladesh: Past, present \& a better future. Indonesia, Asia Pacific Networking Group.

Azam, M. S. (2007). Implementation of B2C e-commerce in Bangladesh: The effects of buying culture and e-infrastructure. Advances in Global Business Research, 3(1), 55-81.

Azjen, I. (1985). From intentions to actions: A theory of planned behavior. In Kuhl, J. \& Beckman, J. (Eds.), Action-control: From cognition to behavior (pp. 11-39). Heidelberg, Springer.

Azjen, I. (1991). The theory of planned behavior. Organizational Behavior and Human Decision Processes, 50, 179-211.

Azjen, I., \& Fishbein, M. (1980), Understanding attitudes and predicting social behavior. Englewood Cliffs, NJ: Prentice-Hall. 
Bakta, N. C., \& Sarder, M. M. R. (2007). Online banking: Bangladesh perspectives. Paper prepared for presentation at the XVI Biennial Conference.

Bandura, A. (1997). Self-efficacy: Toward a unifying theory of behavioral change. Psychological Review, 84, 191-215.

Baraghani, S. N. (2007). Factors influencing the adoption of Internet banking (Unpublished doctoral dissertation). Department of Business Administration and Social Sciences, Lulea University of Technology.

Battacherjee, A. (2002). Individual trust in online

- firms: Scale development and initial trust. Journal of Management Information Systems, 19(1), 211-41.

Baten, M. A., \& Kamil, A. A. (2010). E-Banking of economical prospects in Bangladesh. Journal of Internet Banking and Commerce, 15(2), 1-10.

Byford, K. S. (1998). Privacy in cyberspace: Constructing a model of privacy for the electronic communications environment. Rutgers Computer \& Technology Law Journal, 24, 1-74.

Byron, R. K., \& Ahmed, N. I. (2009). Banking enter new era. Daily Star, Nov. 3, 1-1.

Chang, H. H., \& Hamid, M. R. (2010). An empirical investigation of Internet banking in Taiwan. Global Journal of Business Research, 4(2), 39-47.

Cole, M., \& Brooks, L. (2009). Social aspects of social networking. International Journal

of Information Management, 29, 248.
- Coppola, N., S. R. Hiltz, \& N. Rotter (2004). Building trust in virtual teams. IEEE Transactions on Professional Communication, 47(2), 95-104.

Cranor, L. F. (2000). Beyond concern: Understanding net users' attitudes about online privacy. In Vogelsang, I. \& Compaine, B.M. (Eds.), The Internet upheaval: Raising questions, seeking answers in communications policy (pp. 47-70). Cambridge, MA: The MIT Press.

Culnan, M. (1993). How did they get my name? An exploratory investigation of consumer attitudes toward secondary information use. MIS Quarterly, 17(3), 341-63.
Davis, F. D., Bagozzi, R. P., \& Warshaw, P. R. (1989). User acceptance of computer technology: A comparison of two theoretical models. Management Science, 35(8), 982- 1003.

DeVellis, R. F. (2003). Scale development: Theory and applications (2nd ed.). Thousand Oaks: Sage Publishers.

Doyle, S. (2006). The evolution of self service environments and their potential business impact. Journal of Database Marketing \& Customer Strategy Management, 13(3), 236-243.

Durkin, M. (2007). In search of the Internetbanking customer: Exploring the use of decision styles. International Journal of Bank Marketing, 22(7), 484-503.

Encyclopedia Britannica (2006). New Delhi, India, Encyclopedia Britannica (India) Pvt. Ltd. and Impulse Marketing.

Fogel, G., \& Nehmad, E. (2009). Internet social network communities: Risk taking, trust, and privacy concerns. Computers in Human Behavior, 25, 153-160.

Frye, N. E., \& Dornisch, M. M. (2010). When is trust not enough? The role of perceived privacy of communication tools in comfort with self-disclosure. Computers in Human Behavior, 26, 1120-1127.

Gambi, S. (2009). The development of trust within close relationships formed within social network sites. In Proceedings of the WebSci'09: Society On-Line. Athens, Greece, March 18-20, 2009.

Gan, C., \& Clemes, M. (2006). A logit analysis of electronic banking in New Zealand. International Journal of Bank Marketing, 24(6), 360-383.

George, J. F. (2002). Influences on the intent to make Internet purchases. Internet Research, 12(2), 165-180.

Giannakoudi, S. (1999). Internet banking: The digital voyage of banking and money in cyberspace. Information and Communications Technology Law, 8(3), 205-43.

GVU. (1997). GVU's WWW user survey. Retrieved from www.gvu.gatech.edu/ user_surveys. 
Hernando, I., \& Nieto, M. J. (2007). Is the Internet delivery channel changing banks' performance? The case of Spanish banks. Journal of Banking and Finance, 31, 1083-1099.

Hoffman, D. L., Novak, T. P., \& Peralta, M. (1999). Building consumer trust online. Communications of the ACM, 42(4), 8085.

Huang, J., Makoju, E., Newell, S., \& Galliers, R. D. (2003). Opportunities to learn from 'failure' with electronic commerce: A case study of electronic banking. Journal of Information Technology, 18, 17-26.

Jarvenpaa, S. L., Tractinsky, N., \& Vitale, M. (2000). Consumer trust in an Internet store. Information Technology and Management, 1, 45-71.

Jarvenpaa, S. L., \& Todd, P. A. (1997a). Is there a future for retailing on the Internet? In Peterson, R.A. (Ed.), Electronic Marketing and the Consumer (pp. 139-54). Thousand Oaks, CA: Sage Publication.

Jarvenpaa, S.L., \& Todd,P.A.(1997b). Consumer reactions to electronic shopping on the World Wide Web. International Journal of Electronic Commerce, 1(2), 59-88.

Jarvenpaa, S. L., Knoll, K., \& Leidner, D. E. (1998). Is anybody out there? Antecedents of trust in global virtual teams. Journal of MIS, 14(4), 29-64.

Jones, J. M., \& Vijayasarathy, L. R. (1998). Internet consumer catalog shopping: Findings from an exploratory study and directions for future research. Internet Research, 8(4), 322-30.

Joinson, A. N. (2008). 'Looking at', 'Looking up' or 'Keeping up with' people? Motives and uses of facebook. In Proceedings of CHI 2008, 1027-1036. New York, NY: ACM Press.

Kim, M. S., \& Ahn, J. H. (2007). Management of trust in the e-Marketplace: The role of the buyer's experience in building trust. Journal of Information Technology, 22, 119-132.

Khalifa, M., \& Limayem, M. (2003). Drivers of Internet shopping. Communications of the ACM, 46(12), 233-239.
Langendorfer, P. (2002). M-commerce: Why it does not fly (yet?). Proceedings of the International Conference on Advances in Infrastructure for e-business, e-education, e-science and e-medicine on the Internet, L'Aquila.

Lee, M. K. O., \& Turban, E. (2001). A trust model for consumer Internet shopping. International Journal of Electronic Commerce, 6(1), 75-91.

Limayem, M., Khalifa, M., \& Frini, A. (2000). What makes consumers buy from Internet? A longitudinal study of online shopping. IEEE Transactions on Systems, Man, and Cybernetics - Part A: Systems and Humans, 30(4), 421-32.

Litman, J. (2000). Information privacy / information property. Stanford Law Review, 52(5), 1251-1283.

Liu, C., Marchewkab, J. T., Luc, J., \& Yu, C. (2005). Beyond concern-a privacytrust-behavioral intention model of electronic commerce. Information \& Management, 42, 289-304.

Maheswaran, M., Tang, H. C., \& Ghunaim, A. (2007). Towards a gravity-based trust model for social networking systems. Proceedings of the 27th International Conference on Distributed Computing Systems Workshops, p.24, June 22-29.

McKnight, D. H., Cummings, L. L., \& Chervany, N.L. (1998). Initial trust formation in new organizational relationships. Academy of Management Review, 23(3), 473-490.

McKnight, D. H., Choudhury, V., \& Kacmar, C. (2002). Developing and validating trust measures for e-commerce: An integrative typology. Information Systems Research, 13(3), 334-359.

Metzger, M. J. (2004). Privacy, trust and disclosure: Exploring barriers to electronic commerce. Journal of Computer-Mediated Communication, 9(4), 1-10.

Mia, et. al. (2007). E-banking: evolution, status and prospects. The Cost and Management. 35(1), 36-48.

Miyazaki, A. D., \& Fernandez, A. (2001). Consumer perceptions of privacy and 
security risks for online shopping. Journal of Consumer Affairs, 35(1), 27-44.

Mukherjee, A., \& Nath, P. (2003). A model of trust in online relationship banking. International Journal of Bank Marketing, 2l(1), 5-15.

Nath, R., Paul S., \& Monica P. (2001). Bankers' perspectives on Internet banking. e-Service Journal, 1(1), 21-36.

Nelson, P., \& Richmond, W. (2007). Internet banking: Gold mine or money pit? Academy of Banking Studies Journal, $6(1), 1-25$.

Parameswaran, M., \& Whinston, A. B. (2007). Research issues in social computing. Journal of the Association of Information Systems, 8(6), 336-350.

Pavlou, P. A., \& Gefen, D. (2004). Building C) effective online marketplaces with institution-based trust. Information Systems Research, 15(1), 37-5.

Pavlou, P. A. (2003). Consumer acceptance of electronic commerce --- integrating trust and risk with the technology acceptance model. International Journal of Electronic Commerce, 7(3), 69-103.

Pavlou, P. A. (2002). What drives electronic commerce? A theory of planned behavior perspective. Academy of Management Proceedings, 2002, A1-A6.

Pearce, J. L., Branyiczki, I., \& Balacsi, G. (1994). Person-based reward systems: A theory of organizational reward practices in reform-communist organizations. Journal of Organizational Behavior, 15, 261-82.

Piccoli, G., \& B. Ives (2003). Trust and the unintended effects of behavior control in virtual teams. MIS Quarterly, 27(3), 365-395.

Salehi, M., \& Zhila, A. (2008). Fraud detection and audit expectation gap: Empirical evidence from Iranian bankers. International Journal of Business and Management, 3(10), 65-77.

Salehi, M., Ali, M., \& Zhila, A. (2008). Islamic banking practice and satisfaction: Empirical evidence from Iran. ACRM Journal of Business and Management Research, 3(2), 35-41.
Rahman, M. M. (2007). Innovative technology and bank profitability: The Bangladesh experience. Policy Analysis Unit (PAU), Bangladesh Bank WP 0803.

Ratnasingham, P. (1998). The importance of trust in electronic commerce. Internet Research, 8(4), 313-321.

Samuelson, P. (2000). Privacy as intellectual property. Stanford Law Review, 52(5), 1125- 1175 .

Sarel, D., \& Marmorstein, H. (2003). Marketing online banking services: The voice of the customer. Journal of Financial Services Marketing, 8(3), 106-118.

Sciglimpaglia, D., \& Ely, D. (2006). Customer account relationships and e-Retail banking usage. Journal of Financial Services Marketing, 10(4), 109-122.

Shah, M. H., \& Siddiqui, F. A. (2006). Organizational critical success factors in adoption of e-banking at the Woolwich Bank. International Journal of Information Management, 26(6), 442456.

Shih, Y., \& Fang, K. (2004). The use of a decomposed theory of planned behavior to study Internet banking in Taiwan. Internet Research, 14(3), 213-223.

Shin, D. (2010). The effects of trust, security and privacy in social networking: A security-based approach. Interacting with Computers, 10, 1-35.

Song, J., \& Zahedi, F. (2001). Web design in e-commerce: A theory and empirical analysis. Proceedings of the $22^{\text {nd }}$ International Conference on Information Systems, 205-20.

Smith, H. J., Milberg, S. J., \& Burke, S. J. (1996). Information privacy: Measuring individuals' concerns about organizational practices. MIS Quarterly, 20(2), 167-95.

Suh, B., \& Han, I. (2003). The impact of customer trust and perception of security control on the acceptance of electronic commerce. International Journal of Electronic Commerce, 7(3), 135-161.

Swire, P. P., \& Bermann, S. (2007). Information privacy, official reference for the certified information privacy professional (CIPP). New York: Iapp Publication. 
Tan, M., \& Teo, T. S. H. (2000). Factors influencing the adoption of Internet banking. Journal of the Association for Information Systems, 1(5), 1-42.

Taylor, S., \& Todd, P.A. (1995a). Understanding information technology usage: A test of competing models. Information Systems Research, 6(2), 144-176.

Taylor, S., \& Todd, P.A. (1995b). Assessing IT usage: The role of prior experience. MIS Quarterly, 19(4), 561-70.

Varian, H. R. (1992). Microeconomic analysis (3rd ed.). New York, Norton, W.W.
Warren, S. D., \& Brandeis (1890). The right to privacy. Harvard Law Review, 4(4), 193220.

Weiss, S. (2009). Privacy threat model for data portability in social network applications. International Journal of Information Management, 29, 249-254.

Wright, D., Gutwirth, S., Friedewaldc, M., Hert, P. D., Langheinrichd, M., \& Moscibroda, A. (2009). Privacy, trust and policymaking: Challenges and responses. Computer Law and Security Review, 25, 69-83. 